\title{
Investigation of the glutathione S-transferase gene M1/T1 and angiotensin converting enzyme gene I/D polymorphism in type 1 diabetic patients and possible association with diabetic microvascular complications
}

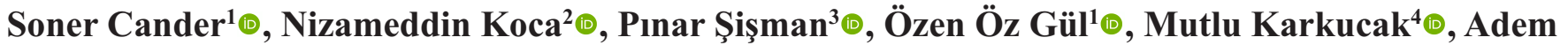 \\ Deligönül ${ }^{5}$, Canan Ersoy $^{1 \oplus}$
}

${ }^{1}$ Department of Endocrinology and Metabolism, Bursa Uludağ University School of Medicine, Bursa, Turkey

${ }^{2}$ Department of Internal Medicine, University of Health Science, Bursa Yüksek İhtisas Training and Research Hospital, Bursa, Turkey

${ }^{3}$ Department of Endocrinology and Metabolism, Bursa Medicana Hospital, Bursa, Turkey

Training and Research Hospital, Bursa, Turkey

${ }^{4}$ Department of Medical Genetic, Sakarya Training and Research Hospital, Sakarya, Turkey

${ }^{5}$ Department of Medical Oncology, Bursa Uludağ University School of Medicine, Bursa, Turkey

\section{ABSTRACT}

Objectives: Glutathione S-transferase (GST) polymorphism may play a role in the etiology of type 1 diabetes, as GST is involved to detoxification of reactive oxygen radicals and synthesis of proinflammatory mediators. Genetic polymorphisms in the renin-angiotensin aldosterone system, including angiotensin converting enzyme (ACE) gene insertion-deletion (I/D) polymorphism, can affect the progression of diabetes and diabetic complications. In our study we aimed to investigate the GST and ACE gene I/D polymorphism in type 1 diabetic patients for comparison with population and relationships with diabetic complications.

Methods: A total of 116 type 1 diabetic patients were included to study. ACE polymorphism analyzed in the 71 subjects and GST polymorphism analyzed in the 62 subjects as control groups. Polymorphism of DNA samples was studied by PCR technique. Results compared with control groups and studied according the diabetic complications.

Results: ACE gene DD genotype and D allele ratio in the patient group were significantly higher than control group. GST T1 and GST M1 ratios were similar between patient and control groups. ACE genotype group distributions and GST M1/T1 genotype ratios were not different in terms of obesity, glycemic control, duration of diabetes and hypoglycemia frequency and not changed according to diabetic complications.

Conclusions: DD genotype and D allele ratio in diabetic patient group were found to be significantly higher and so a significant relationship was observed between and ACE I/D gene polymorphism and type 1 diabetes. On the other hand, it was observed that ACE I/D and GST gene polymorphism did not have any significant effect on diabetic microvascular complications.

Keywords: Type 1 diabetes, ACE gene polymorphism, GST gene polymorphism, diabetic complications 
$\mathrm{D}$ iabetes mellitus (DM), is a major public health problem that genetic and environmental factors play a role in the pathogenesis, is increasingly prevalent throughout the world [1]. According to IDF 2017 data, there are 451 million diabetic patients worldwide and it is estimated that the number of diabetic patients will reach 693 million by 2045 [2]. Type 1 diabetes accounts for $5-10 \%$ of all diabetes cases. The rate of $\beta$-cell damage leading to the disease may vary slightly between individuals, with being faster in infants and children and slower in adults [3]. Auto-reactive T cells and autoimmunity that caused by proinflammatory cytokines and reactive oxygen radicals, are responsible for pancreatic $\beta$-cell damage. Studies in monozygotic twins have reported that environmental components may play a role in $20-60 \%$ of pathogenesis [4].

Oxidative stress resulting from impaired balance between free oxygen radicals and antioxidants plays an important role in the etiopathogenesis of type $1 \mathrm{di}-$ abetes and in the development of diabetic complications [5]. Glutathione, which is a major antioxidant synthesized in many cells, plays a role in the neutralization of free radicals and in the immune response. Glutathione-s-transferase (GST) represents the enzyme family that catalyzes conjugation and elimination of the substrates such as free radicals or xenobiotics. Polymorphisms in the glutathione-stransferase mu 1 (GSTM1) and glutathione-s-transferases theta 1 (GSTT1) genes lead to decreased enzymatic activation and homozygous deletion (null) in both genes leads to a complete loss of enzyme activity. GSTM1 and T1 polymorphism are thought to be associated with many diseases such as allergy, bronchial asthma, coronary artery disease and hypertension $[4,6]$. Considering the role of reactive oxygen radicals and proinflammatory mediators in the pathogenesis of pancreatic beta cell damage, GST polymorphism may play a role in the etiology of type 1 diabetes, as GST is involved in processes such as detoxification of reactive oxygen radicals and synthesis of proinflammatory mediators.

Angiotensin converting enzyme (ACE) insertiondeletion (I/D) polymorphism occurs at the intron 16 of the ACE gene, localized on chromosome 17. While, $\mathrm{ACE}$ activity was highest in the presence of $\mathrm{D}$ allele, it has lowest activity with I allele. Circulating ACE levels in plasma are $30 \%$ higher in ID heterozygotes and $60 \%$ higher in DD homozygotes when compared to II homozygotes $[7,8]$. Genetic polymorphisms in the renin-angiotensin aldosterone system (RAAS), including ACE I/D polymorphism, can affect the progression of diabetes and diabetic complications [9].

In our study, it was planned to investigate the GST and ACE gene I/D polymorphism in type 1 diabetic patients and to investigate possible association with diabetic microvascular complications.

\section{METHODS}

\section{Patients and Protocol}

A total of 116 patients between 18 and 65 years of age who were followed up in the endocrinology outpatient clinic with the diagnosis of type 1 diabetes for at least one year were included in this study. Patients with malignancy or chronic disease which is not associated with diabetes and pregnant patients were not included in the study. The control group was selected for age and gender matched patients without diabetes. ACE polymorphism analyzed 71 subjects and GST polymorphism analyzed 62 subjects were included in the study as separate control groups. Patients' files, including height, weight, HbA1c, daily insulin doses, hypoglycemic episodes, presence of diabetic microvascular complications, findings at the last visits were recorded and examined in detail. Hypoglycemic events are classified as minor hypoglycemia (often: more than once per week, rare: one per week or less) and major hypoglycemia (often: more than once a year, rare: one per year or less). Patients, those with urinary microalbuminuria/creatinine levels between 30 and $100 \mathrm{mg}$ were classified as microalbuminuria, those over $100 \mathrm{mg}$ as macroalbuminuria, those with a glomerular filtration rate of less than $50 \mathrm{ml} / \mathrm{min}$ were classified as chronic renal insufficiency. Presence of retinopathy was assessed according to the final retinal examination. The presence of neuropathy was evaluated with complaints of the patient and physical examination findings in detail. Clinical and laboratory parameters recorded patients' blood samples was taken for genetic analysis and stored at $-20{ }^{\circ} \mathrm{C}$ in EDTA.

\section{Genetic Analysis}

Genomic DNA isolation was performed using the DNA isolation kit (Dr. Zeydanli Life Sciences, Turkey) procedure from blood samples. The ACE 
gene I/D polymorphism of DNA samples was detected by PCR technique. F: 5'-CTG GAG ACC ACT CCC ATC CTT TCT 3 ', R: 5' GAT GTG GCC ATC ACA TTC GTC AGA T-3' primary was used for the ACE I/D polymorphism, F: 5 '-TGG GAC CAC AGC GCC CGC CCG CCA CTA C-3', R: 5'-TCG CCA GCC CTC CCA TGC CCA TAA-3 ' was used as insertion region specific primer to confirm DD genotype. A 30 $\mu \mathrm{L}$ volume PCR mix was prepared for amplification of the ACE gene region from DNA samples. For each sample, the mixture contained $2.5 \mu 1$ of $10 \mathrm{X}$ Taq polymerase buffer, $0.5 \mu 1$ of dNTP mixture of $10 \mathrm{mM}, 2 \mu \mathrm{l}$ of $\mathrm{MgCl} 2$ of $25 \mathrm{mM}, 1 \mu \mathrm{l}$ of 10 pmol of primary pair, $0.2 \mu \mathrm{l}$ of Taq polymerase enzyme (Bioron) and $20 \mu \mathrm{L}$ of ddH2O. Approximately $3 \mu \mathrm{l}(100 \mathrm{ng})$ DNA sample was added to the mix. The samples in the ACE DD genotype were confirmed by PCR for the second time to avoid false DD genotyping. PCR conditions consisted of denaturation at $94{ }^{\circ} \mathrm{C}$ for 1 minute followed by denaturation at $94^{\circ} \mathrm{C}$ for 5 minutes, 1 minute at 57 ${ }^{\circ} \mathrm{C}$ for connection $\left(63{ }^{\circ} \mathrm{C}\right.$ to confirm the DD genotype), extension for 1 minute at $72{ }^{\circ} \mathrm{C}$ for 35 cycles and the final elongation was performed at $72{ }^{\circ} \mathrm{C}$ for 10 minutes. For PCR amplification, samples were run on $2 \%$ agarose gel electrophoresis, stained with ethidium bromide and then photographed. In the agarose gel, 190 base pairs (bp) amplification bands were observed in the samples with DD genotype, 490 and 190 bp with ID genotype and $490 \mathrm{bp}$ in samples with genotype II (Fig. 1). In the second PCR analysis for DD confirmation, amplification band of 335 bp was observed in the samples with the insertion band.

In isolated DNA, the multiplex PCR method was used to determine the polymorphism of the GST M1 and GST T1 genes. Primers for forward 5'-TTCCTTACTGGTCCTCACATCTC-3 'and reverse 5'TCACCGGATCATGGCCAGCA-3' for GST-T1 polymorphism, forward 5'-GAACTCCCTGAAAAGCTAAAGC-3 'and reverse 5'GTTGGGCTCAAATATACGGTGG-3' primers for GST-M1 polymorphism and for the purpose internal controls, the primers albumin forward 5'-GCCCTCTGCTAACAAGTCCTAC-3 'and reverse 5'-GCCCTAAAAAGAAAATCCCCAATC-3' were used. 15, 16th PCR conditions were performed as 35 cycles of $1 \mathrm{~min}$ at $94{ }^{\circ} \mathrm{C}$ (denaturation), $1 \mathrm{~min}$ at $58^{\circ} \mathrm{C}$ (annealing), $1 \mathrm{~min}$ at $72^{\circ} \mathrm{C}$ (elongation) and finally $10 \mathrm{~min}$ at $72{ }^{\circ} \mathrm{C}$ (last extension) after first denaturation at $94{ }^{\circ} \mathrm{C}$ for 5 minutes. $350 \mathrm{bp}$ for albumin, $219 \mathrm{bp}$ for GSTM1 and $459 \mathrm{bp}$ for GSTT1 were expected to occur. The resulting products were run on ethidium bromide containing $2 \%$ agarose gel for evaluation. First, a control 350 -bp product line of the albumin gene, which indicates whether the reaction has taken place, was checked. If there is no control product, PCR is repeated. The genotype determination was made as a

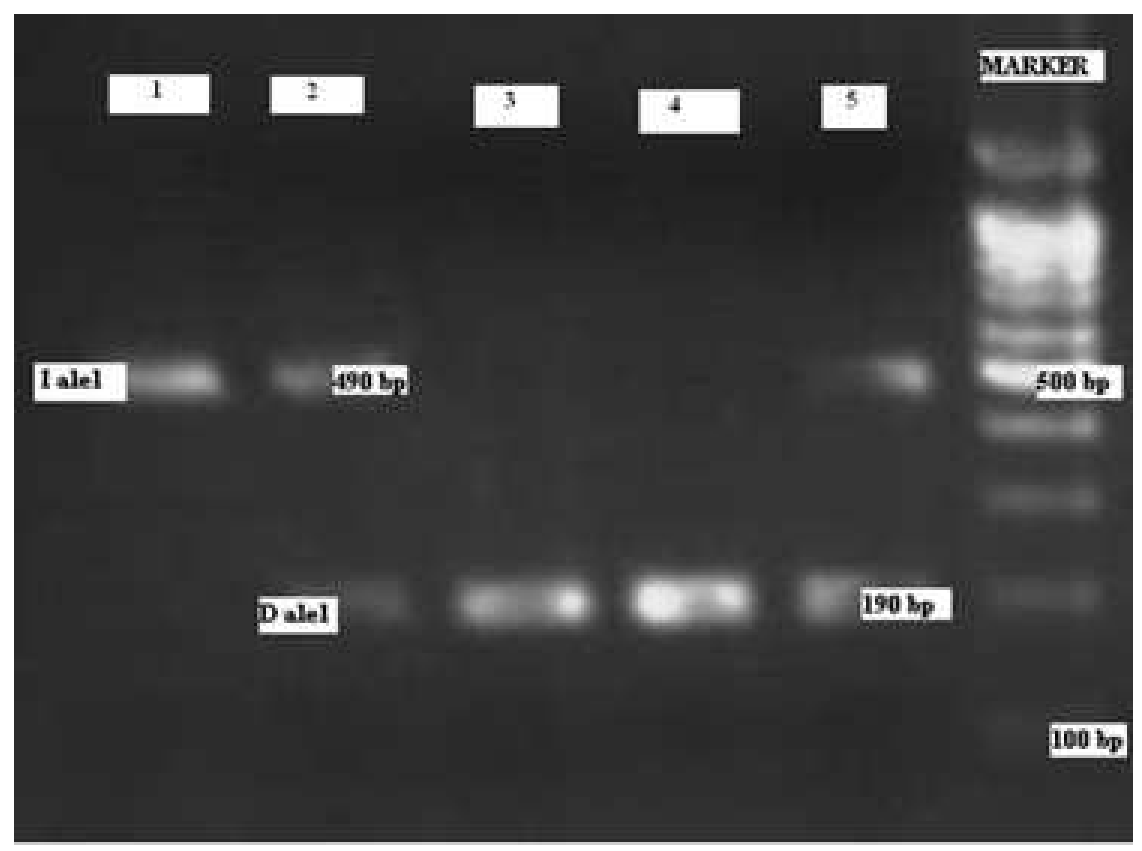

Fig. 1. Agarose gel image of PCR products made with ACE primers. The final well is a 100 bp DNA ladder (Marker), first well is case with genotype II, 2 nd and 5th wells with DD genotype, 3rd and 4th wells with ID genotype. 
'positive genotype' if the GSTT1 gene (459 bp) and the GSTM1 gene (219 bp) were present, or as a 'negative (null) genotype' indicating the presence of homozygote deletion.

\section{Statistical Analysis}

Demographic characteristics, HbA1c, age (years), gender, diabetes duration (years), BMI $(\mathrm{Kg} / \mathrm{m} 2)$ are summarized with descriptive statistics, including mean and standard deviation (values are given in parentheses) for continuous variables and frequency and percentages for categorical variables. Chi-square, Kruskal-Wallis and Mann-Whitney U variance analysis tests were used where they are convenient in the rates of D allele and I alleles in DD, ID, and II genotype groups in ACE gene polymorphism, in evaluation of GST T1 and M1 polymorphism-positive patients' rates in patients' classified according to patient / control, glycemic control and microvascular complications. Pearson and Spearman's correlation coefficients were calculated to assess the associations between variables. All analyses were performed using IBM
SPSS $20^{\mathrm{TM}}$ (SPSS Inc., Chicago, IL, USA) and $p$ values $<0.05$ were considered statistically significant.

\section{RESULTS}

The mean age of the 116 patients was $31 \pm 9.4$ years and the female / male ratio was $72 / 44$. For ACE gene polymorphism 74 control subjects and for GST polymorphism 62 control subjects were included in the study. The age and sex distribution of the patients and control groups are given in table 1 . The mean duration of diabetes was $12.5 \pm 8.1$ years and the $\mathrm{HbA} 1 \mathrm{c}$ level was $75 \mathrm{mmol} / \mathrm{mol}(9.0 \pm 1.9 \%)$ in the patients. In the control group, ACE gene D/I genotype distributions were $35.1 \%$ DD, $41.9 \%$ ID and $23 \%$ II. In type 1 diabetes patients, the DD genotype was $44 \%$, the ID genotype $45.7 \%$ and the II genotype $10.3 \%$. The D allele rate was $66.8 \%$ in the patient group and $56.1 \%$ in the control group. The weighted genotypes and alleles were the same in both groups (ID genotype and D allele). On the other hand, DD genotype and D allele

Table 1. Clinical characteristics and genotypes of diabetic and healthy control group

\begin{tabular}{|c|c|c|c|c|c|c|c|}
\hline & & $\begin{array}{c}\text { Patients } \\
n=116\end{array}$ & $\begin{array}{c}\text { Control I } \\
\mathrm{n}=74\end{array}$ & $\begin{array}{c}\text { Control II } \\
n=62\end{array}$ & $p$ value & $\begin{array}{l}\text { Odds } \\
\text { Ratio }\end{array}$ & $\% 95 \mathrm{CI}$ \\
\hline Age (years) & & $31.0 \pm 9.4$ & $33.0 \pm 5.1$ & $31.0 \pm 5.6$ & $\begin{array}{l}0.10^{\mathrm{a}} \\
0.93^{\mathrm{b}}\end{array}$ & & \\
\hline Gender (F/M) & & $72 / 44$ & $37 / 37$ & $38 / 24$ & $0.10^{\mathrm{a}} / 0.92^{\mathrm{b}}$ & & \\
\hline DD (years) & & $12.5 \pm 8.1$ & & & & & \\
\hline Weight (kg) & & $61.5 \pm 9.5$ & & & & & \\
\hline BMI $\left(\mathrm{kg} / \mathrm{m}^{2}\right)$ & & $22.3 \pm 3.3$ & & & & & \\
\hline $\mathrm{HbAlc} \%$ & & $9.0 \pm 1.9$ & & & & & \\
\hline $\mathrm{mmol} / \mathrm{mol}$ & & 75 & & & & & \\
\hline \multirow{3}{*}{$\begin{array}{l}\text { ACE gene D/I } \\
\text { genotype }\end{array}$} & DD \% & 44.0 & 35.1 & & 0.04 & 1.45 & $0.79-2.64$ \\
\hline & ID \% & 45.7 & 41.9 & & & 1.17 & $0.65-2.10$ \\
\hline & II \% & 10.3 & 23.0 & & & 0.35 & $0.15-0.80$ \\
\hline \multirow{2}{*}{$\begin{array}{l}\text { ACE gene } \mathrm{D} / \mathrm{I} \\
\text { allel rates }\end{array}$} & $\mathrm{D}$ all \% & 66.8 & 56.1 & & 0.04 & 1.49 & $0.97-2.27$ \\
\hline & I all \% & 33.2 & 43.9 & & 0.04 & 0.63 & $0.41-0.97$ \\
\hline \multirow[t]{2}{*}{ GST genotype } & T1\% & 78.4 & & 75.8 & 0.73 & & \\
\hline & M1 \% & 37.9 & & 45.2 & 0.35 & & \\
\hline
\end{tabular}

$\mathrm{DD}=$ Diabetes duration, $\mathrm{BMI}=$ Body Mass Index, $\mathrm{ACE}=$ Angiotensin converting enzyme, $\mathrm{D} / \mathrm{I}=$ deletion/insertion, $\mathrm{GST}=$ Glutathione S-transferase 


\section{Table 2. Relationships between $\mathbf{I} / \mathbf{D}$ polymorphism allelic frequencies and disease releated characters in diabetic patients}

\begin{tabular}{|c|c|c|c|c|c|c|c|c|c|}
\hline & & $\mathbf{n}$ & $\begin{array}{l}\text { DD } \\
\%\end{array}$ & $\begin{array}{l}\text { ID } \\
\%\end{array}$ & $\begin{array}{l}\text { II } \\
\%\end{array}$ & $p$ value & $\begin{array}{l}\text { D allel } \\
\%\end{array}$ & $\begin{array}{l}\text { I allel } \\
\%\end{array}$ & $p$ value \\
\hline \multirow{2}{*}{$\begin{array}{l}\text { BMI } \\
\left(\mathrm{Kg} / \mathrm{m}^{2}\right)\end{array}$} & Normal & 21 & 44.2 & 45.3 & 10.5 & 0.98 & 69.7 & 33.3 & 0.96 \\
\hline & High & 95 & 42.9 & 47.6 & 9.5 & & 69.8 & 33.2 & \\
\hline \multirow{2}{*}{$\begin{array}{l}\mathrm{HbA1c} \\
*\end{array}$} & Low & 14 & 35.7 & 57.1 & 7.1 & 0.65 & 64.3 & 35.7 & 0.67 \\
\hline & High & 102 & 45.1 & 44.1 & 10.8 & & 67.2 & 32.8 & \\
\hline \multirow{2}{*}{$\begin{array}{l}\text { DD } \\
\text { (years) }\end{array}$} & Short $(<10)$ & 56 & 44.6 & 39.3 & 16.1 & 0.11 & 64.3 & 35.7 & 0.61 \\
\hline & Long $(>10)$ & 60 & 43.3 & 51.7 & 5.0 & & 69.2 & 30.8 & \\
\hline \multirow{2}{*}{$\begin{array}{l}\text { Minor } \\
\text { hypoglycemia }\end{array}$} & Rare & 55 & 40.0 & 50.9 & 9.1 & 0.56 & 65.5 & 34.5 & 0.58 \\
\hline & Often & 61 & 47.5 & 41.0 & 11.5 & & 68.0 & 32.0 & \\
\hline \multirow{2}{*}{$\begin{array}{l}\text { Major } \\
\text { hypoglycemia }\end{array}$} & Rare & 101 & 44.6 & 45.5 & 9.9 & 0.90 & 67.3 & 32.7 & 0.68 \\
\hline & Often & 15 & 40.0 & 46.7 & 13.3 & & 63.3 & 36.7 & \\
\hline \multirow[t]{2}{*}{ Nephropathy } & No & 73 & 43.8 & 43.8 & 12.3 & 0.64 & 65.8 & 34.2 & 0.74 \\
\hline & Yes & 43 & 44.2 & 48.8 & 7.0 & & 68.6 & 31.4 & \\
\hline \multirow[t]{2}{*}{ Neuropathy } & No & 91 & 47.3 & 42.9 & 9.9 & 0.39 & 68.7 & 31.3 & 0.21 \\
\hline & Yes & 25 & 32.0 & 56.0 & 12.0 & & 60.0 & 40.0 & \\
\hline \multirow[t]{2}{*}{ Retinopathy } & No & 78 & 44.9 & 44.9 & 10.3 & 0.96 & 67.3 & 32.7 & 0.80 \\
\hline & Yes & 38 & 42.1 & 47.4 & 10.5 & & 65.8 & 34.2 & \\
\hline
\end{tabular}

$\mathrm{DD}=$ Diabetes duration, ${ }^{*}$ Low $=<7 \%$ or $53 \mathrm{mmol} / \mathrm{mol}$, High $=>7 \%$ or $53 \mathrm{mmol} / \mathrm{mol}$

ratio in the patient group were significantly higher and II genotype and I allele ratio were significantly lower than control group $(p=0.04)$ (Table 1). When GST gene polymorphism was examined, T1 positivity was $78.4 \%$ and $75.8 \%$ and $\mathrm{M} 1$ positivity was $37.9 \%$ and $45.2 \%$ in the patient and control group respectively. There was no difference between GST T1 and GST M1 ratios between patient and control groups.

ACE gene polymorphism genotype group distributions were not different in obese and non-obese patients, in patients with and without good glycemic control, in patients with diabetes duration of less ten years or more than 10 years, and in those who had frequent hypoglycemic episodes. Similarly, when assessed for microvascular complications, in terms of genotype distribution and allele ratios, no significant difference was found according to patients with or without nephropathy, retinopathy and neuropathy
(Table 2). GST gene M1/T1 genotype ratios were not different in terms of obesity, glycemic control, duration of diabetes and hypoglycemia frequency. T1 and M1 ratios were similar to those in patients with or without nephropathy, neuropathy and retinopathy (Table 3). There was no statistically significant difference between ACE genotype distribution and allele ratios and nephropathy levels. In patients with microalbuminuria, macroalbuminuria and chronic renal insufficiency, ACE genotype distributions and D/I alleles ratios were not different. Similarly, the GST T1 and GST M1 genotype ratios were similar in the nephropathy subgroups (Table 4).

\section{DISCUSSION}

Oxidative stress is defined as oxidative damage re- 


\begin{tabular}{|c|c|c|c|c|c|c|}
\hline & & n & $\begin{array}{l}\text { T1 } \\
\%\end{array}$ & $p$ value & $\begin{array}{c}\text { M1 } \\
\%\end{array}$ & $p$ value \\
\hline \multirow[t]{2}{*}{ BMI (kg/m²) } & Normal & 21 & 85.7 & 0.37 & 38.1 & 0.97 \\
\hline & High & 95 & 76.8 & & 37.9 & \\
\hline \multirow[t]{2}{*}{ HbA1c* } & Low & 14 & 78.6 & 0.99 & 28.6 & 0.44 \\
\hline & High & 102 & 78.4 & & 39.2 & \\
\hline \multirow[t]{2}{*}{ DD (years) } & Short $(<10)$ & 56 & 80.4 & 0.63 & 39.3 & 0.77 \\
\hline & Long $(>10)$ & 60 & 76.7 & & 36.7 & \\
\hline \multirow[t]{2}{*}{ Minor hypoglycemia } & Rare & 55 & 76.4 & 0.60 & 36.4 & 0.74 \\
\hline & Often & 61 & 80.3 & & 39.3 & \\
\hline \multirow[t]{2}{*}{ Major hypoglycemia } & Rare & 101 & 80.2 & 0.23 & 34.8 & 0.059 \\
\hline & Often & 15 & 66.7 & & 60.0 & \\
\hline \multirow[t]{2}{*}{ Nephropathy } & No & 73 & 79.5 & 0.73 & 38.4 & 0.90 \\
\hline & Yes & 43 & 76.7 & & 37.2 & \\
\hline \multirow[t]{2}{*}{ Neuropathy } & No & 91 & 80.2 & 0.38 & 38.5 & 0.82 \\
\hline & Yes & 25 & 72.0 & & 36.0 & \\
\hline \multirow[t]{2}{*}{ Retinopathy } & No & 78 & 79.5 & 0.70 & 35.9 & 0.52 \\
\hline & Yes & 38 & 76.3 & & 42.1 & \\
\hline
\end{tabular}

$\mathrm{DD}=$ Diabetes duration, $*$ Low $=<7 \%$ or $53 \mathrm{mmol} / \mathrm{mol}$, High $=>7 \%$ or $53 \mathrm{mmol} / \mathrm{mol}$

Table 4. ACE I/D polymorphism allelic frequencies and glutathione-S-transferase genotype according to the diabetic nephropathy risk

\begin{tabular}{llccccc}
\hline & & $\begin{array}{c}\text { No } \\
\text { Nephropathy } \\
\mathbf{n = 7 3}\end{array}$ & $\begin{array}{c}\text { Micro- } \\
\text { albuminuria } \\
\mathbf{n = 1 9}\end{array}$ & $\begin{array}{c}\text { Macro- } \\
\text { albuminuria } \\
\mathbf{n}=\mathbf{1 1}\end{array}$ & $\begin{array}{c}\text { Chronic } \\
\text { Renal Failure } \\
\mathbf{n}=\mathbf{1 3}\end{array}$ & $\boldsymbol{p}$ value \\
\hline ACE & DD \% & 43.8 & 47.4 & 45.5 & 38.5 & 0.97 \\
& ID \% & 43.8 & 47.4 & 45.5 & 53.8 & \\
& II \% & 12.3 & 5.3 & 9.1 & 7.7 & \\
& D allel \% & 65.8 & 71.1 & 68.2 & 65.4 & 0.95 \\
\hline \multirow{2}{*}{ GST } & I allel \% & 34.2 & 28.9 & 31.8 & 34.6 & \\
\hline & T1 poz \% & 79.5 & 68.4 & 90.9 & 76.9 & 0.53 \\
\hline
\end{tabular}

$\mathrm{ACE}=$ Angiotensin converting enzyme, $\mathrm{D} / \mathrm{I}=$ deletion/insertion, $\mathrm{GST}=$ Glutathione S-transferase

sulting from the disruption of the balance between reactive oxygen radicals and antioxidants. Oxidative stress plays an important role in the pathogenesis of diabetes and in the development of diabetic complications as in malignancies, cardiovascular diseases, kidney diseases and neurodegenerative diseases [1].
Glutathione is one of the most effective antioxidants to prevent cell damage caused by environmental toxins and reactive oxygen radical accumulation. Free oxygen radicals and xenobiotics are neutralized by glutathione through the glutathione-s-transferase enzyme. Glutathione-s-transferase enzyme polymor- 
phisms are known to increase or decrease susceptibility to many diseases [10].

In a study comparing type 1 diabetic patients with healthy controls, the GSTT1 null genotype was found to be twice as frequent in the diabetic group, but there was no significant difference in the incidence of GSTM1 between the two groups [11]. In another study, GST T1 null genotype was found to be statistically more frequent in type 1 diabetic group compared to healthy volunteers, and the result was concluded that GST T1 null genotype increases the frequency of type 1 diabetes by 4.2 -fold [10]. In the study conducted by Hori et al., the relationship between GST and type 2 diabetes was investigated, it is concluded that GST T1 and GST M1 null genotypes was an independent risk factor for the development of type 2 diabetes [12]. The current results were described as GST null genotypes may be associated with low antioxidant enzymatic activity [13]. On the other hand, in a study conducted in type 1 diabetic patients between 0-35 years of age and healthy volunteers in the Caucasian community, the GST M1 null genotype was associated with protection from type 1 diabetes [4]. In our study, at the aspect of GST gene polymorphism, in patient and control groups, T1 positivity were $78.4 \%$ and $75.8 \%$, and M1 positivity was $37.9 \%$ and $45.2 \%$ respectively. GST T1 and GST M1 rates were not different between the groups. The prevalence of GST M1 null genotype frequency $(45.2 \%)$ in the healthy control group was similar to that in European countries (38$62 \%)[14]$.

DD genotype was $44.0 \%$, ID genotype was $45.7 \%$ and II genotype was $10.3 \%$ in type 1 diabetes patients included in our study. The D allele ratio was $66.8 \%$ in the patient group and $56.1 \%$ in the control group. The weighted genotypes and alleles were observed to be identical in both groups (ID genotype and D allele). On the other hand, the DD genotype and D allele ratio in the patient group were significantly higher than the control group, and the II genotype and I allele ratio were significantly lower than the control group. In the study of Hibbert et al., the homozygous genotype II was found to be significantly lower in long-term type 1 diabetic patients [15].

There was no significant difference between ACE gene polymorphism and glutathione-s-transferase polymorphism, obesity, duration of diabetes, glycemic control and hypoglycemia rates in type 1 diabetic pa- tients included in our study.

Diabetes mellitus is the most common cause of chronic kidney disease. It occurs in $20-40 \%$ of diabetic patients and may progress to end-stage renal failure. Many environmental, genetic and epigenetic factors are responsible for the pathogenesis of diabetic nephropathy $[3,7]$. Studies show that renal tubulointerstitial injury plays an important role in the pathogenesis and progression of diabetic nephropathy. Glutathione-s-transferases are thought to play a role in the pathogenesis of diabetic nephropathy as they are present in high concentrations in renal tubules [16]. In our study, T1 positivity was $76.7 \%$ in the diabetic nephropathy patient group while $79.5 \%$ in the nonnephropathy group and M1 positivity was $37.2 \%$ in the nephropathy patient group while $38.4 \%$ in the nonnephropathy group. The results were not statistically significant.

In the literature, the results of studies investigating the role of ACE I/D gene polymorphism in the pathogenesis of diabetic nephropathy are controversial [7]. In a meta-analysis evaluating the results of twelve studies, ACE I/D gene polymorphism was associated with end-stage renal failure in type 2 diabetic nephropathy patients, the same relationship was not observed in type 1 diabetic patients [17]. In another meta-analysis, data from 17 case-control studies in the literature were evaluated and ACE I/D polymorphism was associated with nephropathy in type 1 diabetes, particularly in Asian populations [18]. In our study, the distributions of genotype groups in diabetic nephropathy group was examined, the percentages of DD, ID and II were $44.2 \%, 48.8 \%$ and $7.0 \%$ respectively, and in the non-nephropathy group the percentages were $43.8 \%, 43.8 \%$ and $12.3 \%$ respectively. There was no statistically significant difference between the two groups in terms of ACE gene polymorphism genotype distributions.

In the study by Yang et al. [19], they found that GST T1 homozygote deletion is create a risk for endstage renal failure in diabetic patients, but the same risk was not observed in GST M1 homozygote deletion. When the patients included in the study were grouped according to the presence of nephropathy, microalbuminuria, macroalbuminuria and chronic renal failure, no statistically significant differences were observed between the groups in terms of ACE gene polymorphism and glutathione-s-transferase 
polymorphism.

Diabetic retinopathy is the most common cause of new blindness in the 20-74 age group in developed countries. In addition to the duration of diabetes, poor glycemic control, concomitant nephropathy, hypertension, and dyslipidemia increase the risk of developing retinopathy [3]. In the study conducted by Hovnik et $a l$. , the GSTM1 gene was found to be associated with diabetic retinopathy. As a result of this study, the authors suggested that GSTM1 gene deletion is protective for diabetic retinopathy [20]. Bekris et al. [4], found that GSTM1 gene deletion is protective against the development of type 1 diabetes in children aged 14-20 years. It is thought that the protective effect of GSTM1 null genotype on diabetic retinopathy in type 1 diabetic patients could be explained by the upregulation of the other antioxidant enzymes such as manganese superoxide dismutase with GSTM1 gene deletion [21]. In our study, while T1 positivity was $76.3 \%$ in the diabetic retinopathy group, it was $79.5 \%$ in the non-retinopathy group and, while M1 positivity was $42.1 \%$ in the retinopathy group, it was $35.9 \%$ in the non-retinopathy group. There was no statistically significant difference between the groups.

No significant association was found between ACE I/D polymorphism and the presence of diabetic retinopathy in patients with type 1 diabetes in the Caucasian race [22]. In our study, DD, ID and II genotype groups' percentages of ACE gene polymorphism were $42.1 \%, 47.4 \%$ and $10.5 \%$ in diabetic retinopathy group, respectively, whereas it was $44.9 \%, 44.9 \%$ and $10.3 \%$ in non-retinopathy group respectively. No statistically significant difference between the two groups in terms of ACE gene polymorphism genotype distributions was observed.

Diabetic peripheral neuropathy is asymptomatic up to approximately $50 \%$ in diabetic patients [3]. In type 1 diabetic patients, good glycemic control can effectively prevent diabetic peripheral neuropathy and cardiac autonomic neuropathy [23]. Babizhayev et al. [24] suggested that polymorphism in genes encoding antioxidant enzymes might cause genetic susceptibility in type 1 diabetic patients. In our study, while T1 positivity was $72.0 \%$ in the diabetic neuropathy patient group, it was $80.2 \%$ in the non-neuropathy group and while M1 positivity was $36.0 \%$ in the neuropathic patient group and $38.5 \%$ in the neuropathy group, respectively. There was no significant difference be- tween the groups. Peripheral nerve damage in diabetic patients has been associated with polyol accumulation, AGE products and oxidative stress. One of the mechanisms involved in pathogenesis is that hyperglycemia stimulates NADP oxidase by raising tissue angiotensin levels by RAAS activation, thereby increasing oxidative stress and vascular injury [25]. In our study, the percentages of DD, ID and II genotype groups of ACE gene polymorphism were $32.0 \%, 56.0 \%$ and $12.0 \%$ in the diabetic neuropathy group, respectively, and $47.3 \%, 42.9 \%$ and $9.9 \%$ in the non-neuropathy group, respectively. No statistically significant difference in terms of polymorphism genotype distributions was observed.

In diabetic patients with DD genotype, serum ACE levels are higher and increased RAS activity in diabetic patients is associated with increased ACE levels. The high rate of DD genotype in the patient group in our study supports this. It is possible that increased RAS activity may increase the progression of nephropathy, and some of the cited studies have suggested a relationship between the occurrence of complications, particularly nephropathy, and the DD genotype. In our study, however, DD genotype was not found to be associated with complications. This situation shows that other factors besides the increased RAS activity also affect the complications.

\section{CONCLUSION}

In this study, the relationship between GST genotype and ACE I/D gene mutation and age, gender, duration of diabetes, presence of hypoglycemia and diabetic microvascular complications such as nephropathy, retinopathy and neuropathy in type $1 \mathrm{di}-$ abetic patients was investigated. As a result of our study, DD genotype and D allele ratio in diabetic patient group were found to be significantly higher than that of healthy control group, and II genotype and I allele ratio were found to be significantly lower in diabetic patients, and a significant relationship was observed between and ACE I/D gene polymorphism and type 1 diabetes. On the other hand, the same relationship was not detected in the GST gene polymorphism. However, as a result of our study, it was observed that ACE I/D and GST gene polymorphism did not have any significant effect on diabetic mi- 
crovascular complications. Considering the different results on the subject, studies in the literature suggest that studies involving a higher number of patient groups will be important for the detection of susceptibility genes and for assessing the risk of complications in type 1 diabetic patients in which complex factors play a role in etiopathogenesis.

\section{Ethics Approval and Consent to Participate}

Written informed consent was obtained from each subject following a detailed explanation of the objectives and protocol of the study which was conducted in accordance with the ethical principles stated in the "Declaration of Helsinki" and approved by the institutional ethics committee.

\section{Authors' Contribution}

Study Conception: SC,; Study Design: SC,; Supervision: CE, Funding: SC; Materials: SC; Data Collection and/or Processing: SC, ÖÖG, PŞ, AD; Statistical Analysis and/or Data Interpretation: SC, MK; Literature Review: SC, PŞ; Manuscript Preparation: SC, NK, PŞ and Critical Review: NK, CE.

\section{Conflict of interest}

The author disclosed no conflict of interest during the preparation or publication of this manuscript.

\section{Financing}

The author disclosed that they did not receive any grant during conduction or writing of this study.

\section{REFERENCES}

1. Tabatabaei-Malazy O, Khodaein M, Bitarafan F, Larijani B, Amoli MM. Polymorphism of antioxidant genes as a target for diabetes management. Int J Mol Cell Med 2017;6:135-47.

2. Cho NH, Shaw JE, Karuranga S, Huang Y, da Rocha Fernandes JD, Ohlrogge AW, et al. IDF diabetes altas: Global estimates of diabetes prevalence for 2017 and projections for 2045. Diabetes Res Clin Pract 2018;138:271-81.

3. American Diabetes Association. Standards of medical care in diabetes. Diabetes Care 2016;39(Suppl. 1): S1-119.

4. Bekris LM, Shephard C, Peterson M, Hoehna J, Van Yserloo $\mathrm{B}$, Rutledge E, et al. Glutathione-s-transferase M1 and T1 polymorphisms and associations with type 1 diabetes age-at-onset. Autoimmunity 2005;38:567-75.

5. Rahimi R, Nikfar S, Larijani B, Abdollahi M. A review on the role of antioxidants in the management of diabetes and its com- plications. Biomed Pharmacother 2005;59:365-73.

6. Hayes JD, Flanagan JU, Jowsey IR. Glutatione transferases. Annu Rev Pharmacol Toxicol 2005;45:51-88.

7. Seruga M, Makuc J, Zavrsnik M, Cilensek I, Ekart R, Petrovic D. Polymorphism of angiotensin-converting enzyme (rs4340) and diabetic nephropathy in caucasians with type 2 diabetes mellitus. BJMG 2016;19:29-34.

8. Rahimi Z, Hasanvand A, Felehgari V. Interaction of MTHFR $1298 \mathrm{C}$ with ACE D allele augments the risk of diabetic nephropathy in Western Iran. DNA Cell Biol 2012;31:553-9.

9. Movva S, Alluri RV, Komandur S, Vattam K, Eppa K, Mukkavali KK, et al. Relationship of angiotensin-converting enzyme gen plymorphism with nephropathy associated with type 2 diabetes mellitus in Asian Indians. J Diabetes Complications 2007;21:237-41.

10. Barseem N, Elsamalehy M. Gene polymorphisms of glutathione-s-transferase T1/M1 in Egyptian children and adolescents with type 1 diabetes mellitus. J Clin Res Pediatr Endocrinol 2017;9:138-43.

11. Vojkova J, Durdik P, Ciljakova M, Michnova Z, Turcan T, Babusikova E. The association between gene polymorphisms of glutathione-s-transferase T1/M1 and type 1 diabetes in Slovak children and adolescents. Cent Eur J Public Health 2013;21:8891.

12. Hori M, Oniki K, Ueda K, Goto S, Mihara S, Marubayashi $\mathrm{T}$, et al. Combined glutathione-s-transpherase $\mathrm{T} 1$ and $\mathrm{M} 1$ positive genotype afford protection against type 2 diabetes in Japanese. Pharmacogenomics 2007;8:1307-14.

13. Datta SK, Kumar V, Ahmed RS, Tripathi AK, Kalra OP, Banerjee. Effect of GSTM1 and GSTT1 double deletions in the development of oxidative stress in diabetic nephropathy patients. Indian J Biochem Biophys 2010;47: 100-3.

14. Lin HJ, Han CY, Bernstein DA, Hsiao W, Lin BK, Hardy S. Ethnic distribution of the glutathione transferase $\mathrm{Mu} \mathrm{1-1}$ (GSTm1) null genotype in 1473 individuals and application to bladder cancer susceptibility. Carcinogenesis 1994;15:1077-81. 15. Hibbert ML, Millward BA, Demaine AG. The angiotensin Iconverting enzyme (ACE) locus is strongly associated with age and duration of diabetes in patients with type I diabetes. J Diabetes Complications 1997;11: 2-8.

16. von Scholten BJ, Theilade S, Lajer M, Rossing P. Urinary alpha and pi glutathione $s$ transferases in adult patients with type 1 diabetes. Nephron Extra 2014;4:127-33.

17. Yu ZY, Chen LS, Zhang LC, Zhou TB. Meta-analysis of the relationship between ACE I/D gene polymorphism and end-stage renal disease in patients with diabetic nephropathy. Nephrology (Carlton) 2012;17:480-7.

18. Xu HY, Liu MM, Wang X, He XY. Association of angiotensin-converting enzyme insertion/deletion polymorphism with type 1 diabetic nephropathy: a meta-analysis. Ren Fail 2016;38:1320-27.

19. Hovnik T, Dolzan V, Bratina NU, Podkrajsek KT, Battelino T. Genetic polymorphisms in genes encoding antioxidant enzymes are associated with diabetic retinopathy in type 1 diabetes. Diabetes Care 2009;32: 2258-62.

20. Yang Y, Kao MT, Chang CC, Chung SY, Chen CM, Tsai JJ, et al. Glutathion s-transferase T1 deletion is a risk factor for de- 
veloping end-stage renal disease in diabetic patients. Int J Med 2004;14: 855-9.

21. Donaghue KC, Chiarelli F, Trotta D, Allgrove J, Dahl-Jorgensen K. ISPAD clinical practise consensus guidelines 20062007: microvascular and macrovascular complications. Pediatr Diabetes 2007;8:163-70.

22. Tarnow L, Cambien F, Rossing P, Nielsen FS, Hansen BV, Lecerf L, et al. Lack of relationship between an insertion/deletion polymorphism in the angiotensin I-converting enzyme gene and diabetic nephropathy and proliferative retinopathy in IDDM patients. Diabetes 1995;44:489-94.
23. Ang L, Jaiswal M, Martin C, Pop-Busui R. Glucose control and diabetic neuropathy. lessons from recent large clinical trials. Curr Diab Rep 2014;14:528.

24. Babizhayev MA, Strokov IA, Nosikov VV, Savel'yeva EL, Sitnikov VF, Yegorov YE, et al. The role of oxidative stress in diabetic neuropathy: Generation of free radical species in the glycation reaction and gene polymorphisms encoding antioxidant enzymes to genetic susceptibility to diabetic neuropathy in population of type 1 diabetic patients. Cell Biochem Biophys 2015;71:1425-43. 